\title{
Screening of Rectal Swabs for Carbapenem Non-susceptible Bacteroides fragilis Group Bacteria in Hospitalized Children
}

\author{
Ayşe KARAASLAN*, Nurver Ulger TOPRAK**, Gülşen AKKOÇ*, Öncü AKGÜL**, \\ Eda KEPENEKLI KADAYİFCI*, Sevliya ÖCAL DEMIR*, Nurhayat YAKUT*, Serkan ATICI*, \\ Ahmet SOYSAL*, Mustafa BAKIR*, Güner SÖYLETIR**
}

\section{Screening of Rectal Swabs for Carbapenem Non- susceptible Bacteroides fragilis Group Bacteria in Hospitalized Children}

\begin{abstract}
Objective: The aim of this study was to investigate the carbapenem resistance profiles and risk factors for colonization with carbapenem-resistant Bacteroides group (CR-B) in pediatric patients hospitalized in a tertiary university hospital in Turkey.
\end{abstract}

Material and Methods: A prospective case-control study was performed. Rectal swab specimens $(n=1361)$ were collected from 680 hospitalized pediatric patients. All anaerobic colonies isolated from selective medium were identified using MALDI-TOF (Vitek MS, bioMérieux) automated system and antibiotic susceptibility testing for meropenem by e-test. The presence of the cfiA gene was investigated by PCR method.

Results: A total of 1361 rectal swab specimens were collected from all 680 hospitalized children. During the screening period 80 Bacteroides fragilis group (BFG) microorganisms with a MIC $>0.125 \mathrm{mg} / \mathrm{L}(12 \%)$ were isolated from rectal swab specimens of 680 patients. Seven different $B F G$ species were recovered, the main species were B.fragilis $(n=29 ; 36 \%)$, B.ovatus $(n=16 ; 20 \%)$, B.vulgatus $(n=13 ; 16 \%)$, P.distasonis $(n=12 ; 15 \%)$, B.theoiotomicron ( $n=5 ; 6 \%)$, B.uniformis $(n=4 ; 5 \%)$ and B.caccae $(n=1 ; 1 \%)$. The presence of cfiA gene was detected in $25(31 \%)$ isolates, while $29(36 \%)$ isolates were not susceptible to meropenem (MIC>2 $\mathrm{mg} / \mathrm{L}$ ).

Conclusion: The high carriage rate in our hospitalized children for carbapenem-non-susceptible Bacteroides fragilis group creates a great risk for serious infections and mortality and deserves significant attention.

Keywords: Bacteroides fragilis group, carbapenem nonsusceptible, children
Hastanede Yatan Cocukların Rektal Sürüntülerinde Karbapenem Duyarlı Olmayan Bacteroides fragilis Grup Bakteri Taramast

Amaç: Bu çalışmanın amacı, Türkiye'de üçüncü düzey bir üniversite hastanesinde yatmakta olan çocuk hastalarda karbapenem dirençli Bacteroides grup $(K D-B)$ bakteriler ile kolonizasyon için risk faktörlerini ve karbapenem direnç profilini araştırmaktı.

Gereç ve Yöntem: Prospektif vaka-kontrol çalışmasl uygulandi. Hastanede yatmakta olan 680 çocuk hastadan 1361 rektal swab toplands. Selektif mediumdan izole edilen tüm anaerobik kolonilere identifikasyon için MALDI-TOF (Vitek MS, bioMérieux) otomatize sistem ve meropenem duyarlılı ̆̆ için e-test uygulandı. cfiA geni PCR yöntemiyle araştırildl.

Bulgular: Hastanede yatmakta olan 680 çocuk hastadan 1361 rektal swab topland. Tarama süresince MIC $>0.125$ $\mathrm{mg} / \mathrm{L}$ olan 80 Bacteroides fragilis group (BFG) bakteri izole edildi. Yedi farklı tür BFG saptand, sıklık sırasına göre şöyleydi: B.fragilis ( $n=29 ; \% 36)$, B.ovatus $(n=16$; $\% 20)$, B.vulgatus $(n=13 ; \% 16)$, P.distasonis $(n=12 ; \% 15)$, B.theoiotomicron $(n=5 ; \% 6)$, B.uniformis $(n=4 ; \% 5)$ ve B.caccae $(n=1 ; \% 1) .25$ izolatda (\%31) cfiA geni saptantrken, meropeneme hassas olmama $($ MIC>2 $\mathrm{mg} / \mathrm{L})$ 29 izolatda (\%36) belirlendi.

Sonuç: Çalışmamızda, hastanede yatan çocuklarda karbapenem hassas olmayan Bacteroides fragilis grup bakteriler ile kolonizasyon oranları yüksek bulunmuştur ki, bu durum ciddi enfeksiyonların oluşması, artmış mortalite açısından önemlidir ve dikkate alınmalıdır.

Anahtar kelimeler: Bacteroides fragilis grup, karbapenem hassas olmama, çocuklar

Çocuk Dergisi 2017; 17(4):169-173

\footnotetext{
Alındığı tarih: 23.11.2017

Kabul tarihi: 26.01.2018

*Marmara Üniversitesi Tıp Fakültesi, Çocuk Sağlığı ve Hastalıkları Anabilim Dalı, Çocuk Enfeksiyon Hastalıkları Bilim Dalı

**Marmara Üniversitesi Tıp Fakültesi, Mikrobiyoloji Bölümü

Yazıșma adresi: Prof. Dr. Ahmet Soysal, Küçükbakkalköy Mah.

Vedat Günyol Cad. 28-30, Ataşehir 34865 İstanbul

e-posta: drahmetsoysal20@gmail.com
}

\section{INTRODUCTION}

Bacteroides species are anaerobic, non-sporeforming, gram-negative rods which are the dominating constitutive bacteria of the human intestinal flora and also the major anaerobic pathogen of the suppu- 
rative infections in intraabdominal cavity and pelvis. Also, bacteremia and bone and joint infections have rarely been reported with Bacteroides spp. in children (1). Bacteroides spp. are potentially resistant to a wide diversity of antimicrobial agents. The most effective antimicrobials against Bacteroides spp. are in limited number such as, beta-lactam/beta-lactamase inhibitor combinations, metronidazole and carbapenems (2). Clinically, B.fragilis is the most important species, because it is still the mostly isolated virulent bacteria from clinical isolates ${ }^{(1)}$. However, the carbapenemnon-susceptible Bacteroides fragilis bacteria have been reported in several countries recently with a consequence of treatment failure and mortality ${ }^{(3-5)}$. The mortality rates increase to $60 \%$, if a verified B.fragilis infection is not treated ${ }^{(6)}$. It has been put forward that the generation of the imipenem-hydrolyzing metallo-beta-lactamase enzyme which is encoded by the cfiA gene is responsible for carbapenem resistance among $B$. fragilis strains ${ }^{(7)}$.

In the present study, we investigated the risk factors and carbapenem resistance profiles of Bacteroides spp. with rectal colonization in hospitalized pediatric patients in a tertiary university hospital. As far as we know, this is the first study that investigated risk factors of colonization with Bacteroides spp. in children.

\section{MATERIALS and METHODS}

The study was performed in a tertiary university hospital in Istanbul, Turkey. The hospital has a 649bed capacity, including all major pediatric departments and services, neonatal, and pediatric intensive care units. In the study period, the hospital infection control committee had started to implement rectal culture surveillance for carbapenem- resistant gramnegative bacilli (CR-GNB) colonization in all pediatric units because of CR-GNB infections were documented in intensive care units. Rectal swabs were obtained weekly from all hospitalized patients admitted to the hospital. Carbapenem- resistant Bacteroides spp. were investigated in specimens. Rectal swab specimens $(n=1361)$ were collected from 680 hospitalized pediatric patients, between 2/3/2014, and 5/24/2014 of February, and also between 5/24/2014, and 8/28/2015.
Demographic characteristics of the patients, possible risk factors, such as length of antibiotic usage, intensive care unit (ICU) stay, use of nasogastric catheters, ventilators, use and duration of intravenous (IV) treatments or urinary catheters, therapeutic interventions and underlying chronic disease(s) were recorded retrospectively. A case-control study was conducted, comparing colonized patients of Bacteroides spp. with non-colonized patients at a ratio of $1: 1$. The control patients were randomly chosen among patients who stayed in the same ward during the study period. We accepted colonization with Bacteroides group in patients whom the bacteria could be yielded because of high MIC value (MIC >0.125 mg/L) obtained with meropenem. Also the patients colonized with Bacteroides group with meropenem MIC $>2 \mathrm{mg} / \mathrm{L}$ were accepted as meropenem non-susceptibility group. Colonized patients showed no any symptom of infection due to Bacteroides species.

The study protocol was approved by the Ethics Committee of Marmara University Medical School.

\section{Microbiological methods}

Few studies have investigated carbapenemase-producing Bacteroides fragilis group bacteria in stool samples or rectal swabs. Although a range of different culture media has been proposed to determine carbapenemase activity of aerobic or facultative anaerobic bacteria, there is no specific media for those of BFG bacteria. In this present study, we modified kanamycin vancomycin- laked blood agar supplemented with $0.125 \mathrm{mg} / \mathrm{L}$ meropenem (the screening cut-off MIC values).

Each rectal swab was transferred into $1 \mathrm{ml}$ Mueller Hinton broth. An inoculum volume of $100 \mu \mathrm{L}$ was immediately transferred onto the first kanamycinvancomycin-leaked blood agar plus $0.125 \mathrm{mg} / \mathrm{L}$ meropenem (KVLBA-CARBA) directly and $100 \mu \mathrm{L}$ onto second KVLBA-CARBA plate after overnight anaerobic incubation in $5 \mathrm{ml}$ Brucella Broth (suplemented with vitamin $\mathrm{K}$ and hemin) with a $10 \mu \mathrm{g}$ meropenem disk as a selective medium (BB+CARBA). After 48- hour incubation period in anaerobic atmosphere, different colonies were subcultured for aerotolerance testing. All anaerobic colonies were identi- 
fied using MALDI-TOF (Vitek MS, bioMérieux) automated system and antibiotic susceptibility testing for meropenem by E-test method. MIC: $>2 \mathrm{mg} / \mathrm{L}$ of meropenem was accepted as meropenem non-susceptibility according to EUCAST guidelines ${ }^{(8)}$. The presence of the cfiA gene was investigated by PCR using GBI-1 F 5'- CCCAACTCTCGGACAAAGTG-3 and GBI-2 R 5'-AGTGAATCGGTGAATCCATG-3 primers ${ }^{(9)}$.

\section{RESULTS}

A total of 1361 rectal swab specimens were collected from all 680 hospitalized children between 2/3/2014, and $5 / 24 / 2014$, and also between $8 / 28 / 2014$, and 3/9/2015 -24th of May 2014 and 28th August 20149th March 2015. During the screening period 80 BFG organisms $(12 \%)$ were isolated from rectal swab specimens of 680 patients. Seven different BFG species were recovered, the main species were $B$ fragilis $(\mathrm{n}=29 ; 36 \%)$, B.ovatus $(\mathrm{n}=16 ; 20 \%)$, B.vulgatus $(\mathrm{n}=13 ; 16 \%)$, P.distasonis $(\mathrm{n}=12 ; 16 \%)$, B.theoiotomicron $(\mathrm{n}=5 ; 6 \%)$, B.uniformis $(\mathrm{n}=4 ; 5 \%)$ and B.caccae $(\mathrm{n}=1 ; 1 \%)$. CfiA gene was detected in 25 $(31 \%)$, and the meropenem non-susceptibility $(\mathrm{MIC}>2 \mathrm{mg} / \mathrm{L})$ in $29(36 \%)$ isolates. All of the $c f i A$ gene positive strains $(\mathrm{n}=25)$ were $B$. fragilis and 18 $(72 \%)$ of these strains were meropenem-non-susceptible. Eleven Bacteroides fragilis group strains [B.fragilis $(\mathrm{n}=2)$, P.distasonis $(\mathrm{n}=3)$, B.vulgatus $(\mathrm{n}=3)$, B.ovatus $(\mathrm{n}=1)$, B.uniformis $(\mathrm{n}=1)$, B.caccae $(\mathrm{n}=1)]$ without $c f i A$ were meropenem non-susceptible. All the organisms detected and the MIC values of meropenem are shown in Table 1.
Forty-two (53\%) males and thirty-eight (47\%) females with a mean $( \pm \mathrm{SD})$ age of $76.5 \pm 66.6$ months (range 0-254, median 59 months) were colonized with Bacteroides fragilis group. Among 80 patients, $58(72.5 \%)$ received antibiotic therapy. We investigated risk factors such as carbapenem and other antianaerobic use, length of antibiotic use, intensive care unit (ICU) stay, use of nasogastric catheters, ventilators, use and duration of intravenous (IV) treatment or urinary catheters and underlying chronic disease(s) for colonization with Bacteroides group. We did not identify any risk factors between Bacteroides group with $\mathrm{MIC}>2$ vs Bacteroides group with $\mathrm{MIC} \leq 2$, between cfiA (+) B.fragilis vs cfiA (-) B.fragilis, between $B$.fragilis with $\mathrm{MIC}>2$ vs $B$. fragilis $\mathrm{MIC} \leq 2$ and between non-B.fragilis spp. with $\mathrm{MIC}>2$ vs non- $B$.fragilis spp.with $\mathrm{MIC} \leq 2$.

\section{DISCUSSION}

Bacteroides fragilis is the most common anaerobe of the human colon and it is responsible for different type of infections such as intra-abdominal infections, bacteremia and bone/joint infections in children ${ }^{(1)}$. Accurate and prompt treatment is very important for outcome of these diseases and delayed treatment regimen is associated with mortality ${ }^{(10)}$. In the past two decades, resistance to antimicrobial agents, such as carbapenems, metronidazole and beta-lactam/betalactamase inhibitor combinations has been notified ${ }^{(11)}$. The carbapenemase metallo-beta-lactamase gene (cfiA) is produced by B.fragilis and contributes to carbapenem resistance (7). In our study, cfiA was detected in $31 \%(n=25)$ of bacteria, and all of them

Table 1. All the organisms detected and the MIC values of Meropenem.

\begin{tabular}{|c|c|c|c|c|c|c|c|c|c|c|c|c|}
\hline & \multirow[b]{2}{*}{ Organisms } & \multicolumn{11}{|c|}{ MEROPENEM MIC VALUE (mg/L) } \\
\hline & & 0.25 & 0.5 & 0.75 & 1 & 1.5 & 2 & 3 & 4 & 8 & 12 & 32 \\
\hline \multirow[t]{8}{*}{$\operatorname{cfiA}(-)$} & B.fragilis & 0 & 0 & 0 & 1 & 1 & 0 & 0 & 0 & 0 & 0 & 2 \\
\hline & B. ovatus & 0 & 8 & 0 & 2 & 3 & 2 & 0 & 0 & 0 & 0 & 1 \\
\hline & B. vulgatus & 1 & 4 & 2 & 2 & 0 & 1 & 0 & 0 & 0 & 0 & 3 \\
\hline & P. distasonis & 1 & 4 & 0 & 3 & 1 & 0 & 0 & 0 & 1 & 1 & 1 \\
\hline & B.theaiotomicron & 0 & 0 & 0 & 4 & 0 & 1 & 0 & 0 & 0 & 0 & 0 \\
\hline & B. uniformis & 0 & 0 & 0 & 1 & 1 & 1 & 0 & 0 & 0 & 0 & 1 \\
\hline & B.caccae & 0 & 0 & 0 & 0 & 0 & 0 & 0 & 0 & 0 & 0 & 1 \\
\hline & Total & 2 & 16 & 2 & 13 & 6 & 5 & 0 & 0 & 1 & 1 & 9 \\
\hline \multirow[t]{2}{*}{ cfiA (+) } & B. fragilis & 0 & 2 & 0 & 2 & 0 & 3 & 1 & 1 & 1 & 0 & 15 \\
\hline & Total & 0 & 2 & 0 & 2 & 0 & 3 & 1 & 1 & 1 & 0 & 15 \\
\hline
\end{tabular}

MIC: Minimum inhibitory concentration, B: Bacteroides 
belonged to the B.fragilis spp. In our study, cfiA positive isolates were detected more frequently $(7 \%)$ among clinical isolates relative to those previous reported in France (2\%), Hungary (6\%) and United Kingdom (7\%) ${ }^{(12-14)}$. However our cfiA detection rate was similar to that mentioned (35\%) in the report of Fernandez-Canigia et al ${ }^{(11)}$ for Argentina. In our study, differently from other studies we analyzed samples from patients with rectal colonization. There are not many studies on this issue, so we could't compare our study results. In a previous study from our country, cfiA gene was detected in $27 \%$ of 66 Bacteroides isolates, similar to our study ${ }^{(15)}$.

cfiaA and ccrA genes encode class B metallo-betalactamase enzyme which is responsible for resistance to carbapenem ${ }^{(16)}$. Some Bacteroides fragilis strains contain silent resistance genes and insertion sequences (IS) which are suffixed immediately upstream of the $c f i A / c c r A$ gene, and can upregulate the expression of these carbapenemase genes. Moreover, increased efflux pump activity and changes in porins are possible reasons of resistance to carbapenems ${ }^{(1,17)}$. In this study we determined the carbapenem resistance profiles of Bacteroides species and the presence of the $c f i A$ gene. We found that all of the cfiA gene positive strains $(\mathrm{n}=25)$ were $B$.fragilis and $18(72 \%)$ of these strains were meropenem-nonsusceptible. In other seven strains, IS can provide a promoter to express cfiA gene and these strains can become carbapenem resistant. Also in our study, 11 Bacteroides group strains (B.fragilis $(\mathrm{n}=2)$, P.distasonis $(\mathrm{n}=3)$, B.vulgatus $(\mathrm{n}=3)$, B.ovatus $(\mathrm{n}=1)$, B.uniformis $(\mathrm{n}=1)$, B.caccae $(\mathrm{n}=1))$ without cfiA were meropenem non-susceptible. We think that changes in porins and increased efflux pump activity may be the possible reasons of carbapenem non-susceptibility.

As far as we know, there is no study investigating the risk factors for colonization with meropenem nonsusceptible Bacteroides spp. in children. In this study, we investigated risk factors however we did not identify any risk factors between Bacteroides group with MIC>2 vs Bacteroides group with $£ 2$, cfiA (+) $B$. fragilis vs $c$ fiA (-) B.fragilis, $B$ fragilis with $\mathrm{MIC}>2$ vs $B$ fragilis $\mathrm{MIC}>2$, non- $B$ fragilis species with MIC£2 vs non-B.fragilis species with MIC£2. Because of lack of relevant data, we could not compare our results with any study, for this reason further studies are needed.

In conclusion, high rate of colonization with meropenem non-susceptible Bacteroides spp.is an important and increasing health problem because they are probable agents of serious life-threatining infections. Further studies should be implemented to asses risk factors.

\section{Conflicts of Interest}

The authors declare that they have no conflicts of interests.

\section{Acknowledgements}

All authors have participated in drafting of the manuscript and/or critical revision of the manuscript for important intellectual content. All authors read and approved the final manuscript.

\section{REFERENCES}

1. Wexler HM. Bacteroides: the good, the bad, and the nitty-gritty. Clin Microbiol Rev 2007;20:593-621. https://doi.org/10.1128/CMR.00008-07

2. Snydman DR, Jacobus NV, McDermott LA, et al. Lessons learned from the anaerobe survey: historical perspective and review of the most recent data (20052007). Clin Infect Dis 2010;50:26-33. https://doi.org/10.1086/647940

3. Goldstein EJ, Finegold SM, Harrell LJ, et al. National survey on the susceptibility of Bacteroides fragilis group: report and analysis of trends in the United States from 1997 to 2004. Antimicrob Agents Chemother 2007;51:1649-55. https://doi.org/10.1128/AAC.01435-06

4. Nagy E, Urbán E, Nord CE, et al. Antimicrobial susceptibility of Bacteroides fragilis group isolates in Europe: 20 years of experience. Clin Microbiol Infect 2011;17:371-9. https://doi.org/10.1111/j.1469-0691.2010.03256.x

5. Liu CY, Huang YT, Liao CH, Yen LC, Lin HY, Hsueh PR. Increasing trends in antimicrobial resistance among clinically important anaerobes and Bacteroides fragilis isolates causing nosocomial infections: emerging resistance to carbapenems. Antimicrob Agents Chemother 2008;52:3161-8. https://doi.org/10.1128/AAC.00355-08

6. Goldstein EJ. Anaerobic bacteremia. Clin Infect Dis 1996; 23:97-101. https://doi.org/10.1093/clinids/23.Supplement_1.S97

7. Khushi Payne TDJ, Fosberry A, Reading C. Production of metal dependent b-lactamases by clinical strains of Bacteroides fragilis isolated before 1987. J Antimicrob Chemother 1996;37:345-50. https://doi.org/10.1093/jac/37.2.345 
8. The European Committee on Antimicrobial Susceptibility Testing (EUCAST). http://www.eucast. org/fileadmin/src/media/EUCASTfiles/Resistance_ mechanisms/EUCASTdetection_of_resistance_mechanisms_v1.0_20131211.pdf

9. Kato N, Yamazoe K, Han CG, Ohtsubo E. New insertion sequence elements in the upstream region of cfiA in imipenem-resistant Bacteroides fragilis strains. Antimicrob Agents Chemother 2003;47:979-85. https://doi.org/10.1128/AAC.47.3.979-985.2003

10. Nguyen MH, Yu VL, Morris AJ, et al. Antimicrobial resistance and clinical outcome of Bacteroides bacteremia: findings of a multicenter prospective observational trial. Clin Infect Dis 2000;30:870-6. https://doi.org/10.1086/313805

11. Fernández-Canigia $L$, Litterio M, Legaria MC, et al. Anaerobe Surveillance Team. First national survey of antibiotic susceptibility of the Bacteroides fragilis group: emerging resistance to carbapenems in Argentina. Antimicrob Agents Chemother 2012;56:1309-14. https://doi.org/10.1128/AAC.05622-11

12. Podglajen I, Breuil J, Casin I, Collatz E. Genotypic identification of two groups within the species Bacteroides fragilis by ribotyping and by analysis of
PCR-generated fragment patterns and insertion sequence content. J Bacteriol 1995;177:5270-5. https://doi.org/10.1128/jb.177.18.5270-5275.1995

13. Soki J, Urban E, Szoke I, Fodor E, Nagy E. Prevalence of the carbapenemase gene (cfiA) among clinical and normal flora isolates of Bacteroides species in Hungary. J Med Microbiol 2000;49:427-30. https://doi.org/10.1099/0022-1317-49-5-427

14. Edwards R, Hawkyard CV, Garvey MT, Greenwood D. Prevalence and degree of expression of the carbapenemase gene (cfiA) among clinical isolates of Bacteroides fragilis in Nottingham, UK. J Antimicrob Chemother 1999;43:273-6. https://doi.org/10.1093/jac/43.2.273

15. Toprak NU, Uzunkaya OD, Sóki J, Soyletir G. Susceptibility profiles and resistance genes for carbapenems (cfiA) and metronidazole (nim) among Bacteroides species in a Turkish University Hospital. Anaerobe 2012;18:169-71.

https://doi.org/10.1016/j.anaerobe.2011.10.004

16. Livermore DM, Woodford N. Carbapenemases: a problem in waiting? Curr Opin Microbiol 2000;3:48995.

https://doi.org/10.1016/S1369-5274(00)00128-4 